\title{
CORRESPONDENCE
}

\section{Wrong rodents}

SIR - The discovery that several cell lines claimed to be derived from patients with Hodgkin's disease in fact come from an owl monkey 1 emphasizes the vital importance of quality control in biological research.

Several cases of genetic contamination of inbred strains of laboratory mice and rats have come to light recently, and although these are not associated with any known scientific fraud, they have led in some cases to a considerable disruption of research projects. In the United States, for example, one large commercial breeder appears to have been selling "inbred" Lewis (LEW) rats which are not histocompatible, leading to a flood of complaints from research workers and inevitably casting doubt on the validity of some published work. In Japan, a survey of over 100 colonies of inbred mice ${ }^{2}$ has shown that about 10 per cent had been genetically contaminated either recently (with continued genetic segregation at some loci) or in the more distant past. Indeed many of the major sublines of common inbred strains such as $\mathrm{C} 3 \mathrm{H}$ and $\mathrm{C} 57 \mathrm{BL}$ have arisen as a result of genetic contamination in the past ${ }^{3}$.

In the United Kingdom a voluntary genetic monitoring scheme for commercial breeders was started about five years ago by the Medical Research Council Laboratory Animals Centre and several cases of genetic contamination have been discovered since that time ${ }^{4}$. Both of the main UK suppliers of inbred mice and rats took these results so seriously that they have established their own in-house genetic monitoring programmes run under the direction of consultant geneticists. The International Committee on Laboratory Animal Science (ICLAS) is preparing a handbook on methods of genetic monitoring, and is considering the establishment of some international reference centres for genetic monitoring. In the meantime research workers are strongly urged not to take the authenticity of the strains that they use entirely on trust. If they purchase animals from commercial breeders they should demand to know what steps the breeder is taking to monitor the stock. Those who breed their own strains should remember that accidental contamination can occur at any time, and they should check their stock using skin grafting or some other suitable method (such as the study of biochemical 5 or immunological markers 6 or morphological features such as mandible shape ${ }^{7}$ ) as a matter of routine.

Michael F.W. Festing

\section{MRC Laboratory Animals Centre,} Carshalton, Surrey, UK

. Dickson, D. Nature 289, 227 (1981).

2. Nomura, T. et al. Proc. 7th ICLAS Symposium, Utrech (Fischer, Stuttgart, in the press).

3. Festing, M.F.W. Inbred Strains in Biomedical Research (Macmillan, London, 1979)

4. Festing, M.F.W. \& Lovell, D. Proc, 7th ICLAS Symposium, Utrecht, (Fischer, Stuttgart, in the press). Groen, A. Lab. Anim. 11, 209-214 (1977).

6. Festing, M.F.W. \& Totman, P. Lab. Anim. 14, 173-177 (1980)

Festing, M.F.W. Nature 238, 351-352 (1972).

\section{French museums}

SiR - Seen from this side of the Channel, Halstead's criticisms of the new exhibition policy of the British Museum (Natural History) appear extremely unjust (Nature $\mathbf{2 8 8}$. $208 ; 1980$ ), especially towards the staff who contributed to such clear and remarkable presentation. In France, there is no discussion of that sort, because most of our natural history museums simply have no exhibition policy at all, and are nothing but museums of museums!

Last November, when Halstead was writing his venomous letter, I visited the two new exhibits (on dinosaurs and on the evolution of man) at the British Museum, and was amazed to see how much the public liked them, in particular the children, who seemed very receptive to the logic of cladistic analysis. Halstead's long attack against that method of tracing the interrelationships of living beings deserves more comment. He claims that cladistic analysis, which is the basis of the British Museum exhibits, does not take into consideration the concept of gradualism, according to which evolution can be presented as uninterrupted series of species, older ones being ancestral to younger ones. Hence his accusation against cladism, which is, according to him, trying to make evolution fit Marxist views on the history of societies!

Halstead presents gradualism as evidence, and cladism as a crime against evidence. But where is the evidence of gradualism? There is almost none, or rather it is everywhere one wants to see it.

Cladists do not deny that a species can give birth to daughter species, but they claim that in practice, it is impossible to determine the fossil ancestor of a species, since the ancestor is devoid of the derived characteristics of the daughter-species in question. Ancestordescendant relationship is not, for cladists, a necessary statement, and the history of a group is better expressed by sister-group relationships, often illustrated by a cladogram. Many biostratigraphers are now convinced that successions of species based on stratigraphic distribution are nothing but illusions and that, in reality, each older species is extinguished by the younger one, whose centre of origin may be far from the locality studied. So, the subversive palaeontologists who are supposed to pervade the British Museum, knife between teeth, are simply those who consider that gradualism gives an illusory precision, which is unnecessary for tracing the course of evolution of a group. If these new views are congruent with vague ideological inferences on human societies, so what?. . After all, the history of human societies often shows a succession of leaps, be they revolutions, wars, epidemics, or changes in climate. But major changes in human societies are seldom decided by the societies themselves. The societies and their chiefs want gradual change (compare the terms "changes in continuity" or "permanent revolution" used by right-wing and left-wing politicians respectively), but in the event, circumstances provoke sudden changes.

In France, some authors are now attacking Darwin (see P. P. Grassé, L'homme en
Accusation, Albin Michel, Paris) because he is supposed to have inspired Hitler and still inspires the deeply anti-Marxist sociobiologists. Since cladism is also directly descended from Darwin's ideas on phylogeny and systematics, it can just as well be accused of supporting extreme right-wing ideologies.

In sum, even if some cladists claim that this method of analysis is more consistent with their political convictions, it is simply ridiculous to condemn it on the basis of such spurious arguments, or because Halstead's political opinions are different. The British educational system can be proud of the British Museum's exhibitions which will certainly teach future generations of biologists and palaeontologists the principles of phylogenetic reasoning. Perhaps this is just what Halstead is afraid of?

PhilipPe JanVier

Laboratoire de Paléontologie des Vertébrés, Université Paris VI, France

\section{More museums}

SIR - Halstead's well publicized reactions ${ }^{1-6}$ to the exhibition policies of the British Museum (Natural History), to nongradualistic hypotheses about the evolutionary process, and to his own mistaken perceptions of cladistic analysis are unfortunate ${ }^{7-9}$. His notion that these views somehow abet nonscientific creationist metaphysics or logically support Marxist dialectics is preposterous. Whether Popper ${ }^{10}$, Patterson ${ }^{11}$, or Miles (cited by Halstead in ref.4) have said that the evolutionary concept is also metaphysically based and whether this is true are beside the point. Equating Marxist political theory either with cladistic analysis or with so-called macroevolutionary hypotheses is as wrong as social Darwinism was. It needs to be driven home, as Patterson has done ${ }^{9}$, that cladistic analysis is about pattern, not about any particular hypothesized evolutionary process, although most phylogenetic systematists do hold that descent with modification is an economical explanation of the existence of biological pattern in general. These systematists also define "related" to mean "genealogically related." In all six publications Halstead confuses cladograms with evolutionary trees. For instance, a steady theme is, "there is no place for ancestral species in a cladogram" . Again, "it is axiomatic, therefore, that no species in the fossil record can be ancestral to any other nor can one species evolve directly into another"s Halstead has not understood that cladograms do not assume that species are ancestors, but neither do they deny possible ancestry when a taxon lacks known derived characters. Assumptions of ancestry are appropriate for trees but are not made in cladograms.

Cladistic analysis parsimoniously estimates relatedness and is therefore testable. The British Museum (Natural History) is to be congratulated for bringing epistemology into its exhibits and teaching visitors that science is a method, not a body of revealed knowledge. That the museum may also need to discuss various hypotheses of evolutionary process ${ }^{12}$ 